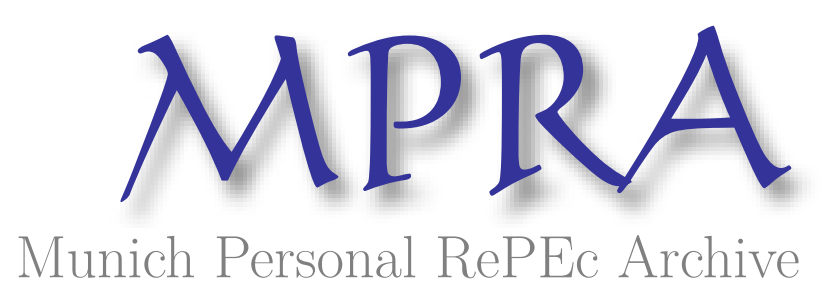

\title{
A Strategy for Improving the Technology Transfer System in Afghanistan through ATMA Model using Participatory Rural Appraisal (PRA) Approach
}

Singh, K.M. and Kumar, Ajay

Rajendra Agricultural University, Bihar, India

8 November 2008

Online at https://mpra.ub.uni-muenchen.de/45692/

MPRA Paper No. 45692, posted 31 Mar 2013 06:06 UTC 


\title{
A Strategy for Improving the Technology Transfer System in Afghanistan through ATMA Model using Participatory Rural Appraisal (PRA) Approach
}

by

\author{
K. M. Singh ${ }^{1}$ \\ Ajay Kumar ${ }^{2}$ \\ Rajendra Agricultural University, Bihar, India
}

\begin{abstract}
The goal of technology transfer is to improve the livelihoods of rural households and communities. This goal is proposed to be achieved by pilot-testing a sustainable and integrated water and land management strategy in selected districts and provinces that will introduce or expand the use of high-value, water-efficient crop and livestock systems to increase farm household income. Where these new agricultural innovations and/or value-added systems are proven to be effective, then the next step will be to scale-up these innovations to other producer/farmer groups within the current and/or other comparable agro-ecological zones/districts within the country. An additional purpose will be to organize farmer, producer, community and/or self-help groups (especially for rural women) at the community level so they can learn procedures for marketing specific high-value crops and products, as well as in managing their water resources at the community level. The paper discusses the methods and strategies using participatory rural appraisal to evolve a workable model for developing the agricultural sector in two provinces of Afghanistan, namely Balkh and Nangarhar.
\end{abstract}

Key words: Participatory Rural Appraisal, Afghanistan, Issues for development, Balkh, Nangarhar

\section{Introduction}

From the conditions under which Afghanistan finds it self at present, to take the country on the paths of development, is a very difficult task, if not impossible. Due to its geographical conditions, peoples and varied agro-climate, Afghanistan is full of strengths, opportunities, weaknesses and threats, so far as agricultural development is concerned. Any passerby who wades through the streets, and bazaar of Afghanistan, which are full with a variety of fruits, vegetables, and livestock can be suitable impressed with the colour, size, and variety of these agricultural products on display in the markets. If probed, it is clear that these beautiful agro products have their origin in the village, orchards and fields of Afghanistan. The phenomenon of selling the local produce particularly fresh fruits, vegetables, and dry fruits is not only evident in areas near the cities but also deep in the country side; at the same time, seeing trucks laden with onion in gunny bags destined for some far off place are a common site on the highways of Afghanistan. Seeing the markets and fields in Afghanistan, it is clear that high value agricultural products like meat, fruits and vegetables, new methods of cultivation, and new crops are being practiced in the villages. Also evident is the fact that the produce has local origins, and that serious efforts are on to bring a change in the agricultural scenario of the country through

\footnotetext{
${ }^{1}$ Professor of Agricultural Economics, R.A.U., Bihar, India

${ }^{2}$ Chief Scientist (Agronomy), R.A.U., Bihar, India
} 
innovations in agricultural production. No doubt, this is the results of the hard work of Afghanistan farmers, working under adverse conditions and of course with some support from the friendly countries/ donors.

While it is true, that a country under civil war for such a long period has a severely damaged infrastructure that is necessary for agricultural development, especially the agricultural research, extension and educational infrastructure in a very poor shape and in need of immediate remedial measure to improve their capacity for taking up the challenges of a globalized economy in the twenty first century.

The strengths, weakness and opportunities of Afghanistan agriculture, the skill and capacity available with the farmers of this country, new experiences, and its pre-war brand equity in the external markets could become the starting point for giving a new direction to Afghanistan agriculture in this globalized $21^{\text {st }}$ century economy.

\section{Participatory Rural Appraisal -Methodology}

\section{Background: Technology Transfer Goals}

The goal of technology transfer is to improve the livelihoods of rural households and communities in selected provinces and districts within Afghanistan by making more productive use of surface- and ground-water resources by helping farmers to;

1) Diversify their farming systems through the use of high-value, water-efficient crop and livestock systems; and

2) Learn how to use more sustainable land and water management practices within different ecosystems in each district.

This goal is proposed to be achieved by pilot-testing a sustainable and integrated water and land management strategy in selected districts and provinces that will introduce or expand the use of high-value, water-efficient crop and livestock systems to increase farm household income. Where these new agricultural innovations and/or value-added systems are proven to be effective, then the next step will be to scale-up these innovations to other producer/farmer groups within the current and/or other comparable agro-ecological zones/districts within the country. An additional purpose will be to organize farmer, producer, community and/or self-help groups (especially for rural women) at the community level so they can learn procedures for marketing specific high-value crops and products, as well as in managing their water resources at the community level.

\section{Orientation at Top: Training the National Extension Staff and Policy makers}

The national and provincial extension officials in MAIL were oriented about this new marketdriven extension model and were exposed to this proposed approach in detail. The orientation was done in Kabul for the senior officers who are responsible for extension policy planning and its implementation in Afghanistan, and also in Mazar-e-sharif and Jalalabad for extension officials at the provincial level. They were informed about the purpose and rational for training the key members of the provincial and district extension staff on how to conduct a PRA and then develop a SREP for the selected district. They were also informed that the exercise would help them identify key constraints and potential market opportunities that can increase farm household income for different types of farm households within each of the two selected district 
falling in the Balkh and Nangarhar provinces. The extension department officers, research workers, teachers \& students from the agriculture faculty and progressive farmers were oriented about the new market-driven extension model in detail. They were informed about the purpose

and rational for the training to be conducted on PRA and then to develop a SREP for the selected districts of Balkh and Nangarhar provinces. They were also informed that this exercise will help in identifying key constraints and potential market opportunities that can increase both yield and household income for different category of farm households in two selected districts (each) in both the Balkh and Nangarhar provinces.

\section{An Overview of PRA Training}

\section{Training the Field Extension Staff}

The training programme on PRA was designed to develop the master trainers for developing SREP in two selected pilot province in Afghanistan with the objective to train the district extension/research workers in Participatory Rural Appraisal (PRA) methodology to collect required information from the village and also to take people participation (and their perceptions) into consideration in developing a Strategic Research and Extension Plan (SREP) for the selected district(s) in both the Balkh and Nangarhar provinces. A team of twenty four persons were also selected for in-depth PRA training in both the pilot provinces. They were selected on the basis of different discipline, namely agronomy, horticulture, livestock, plant protection, and teacher \& students from the agriculture faculty. Their willingness, as well as their knowledge and experience were also considered, so that after the training programme they could carry out the PRA field exercise in the selected villages of the two provinces.

\section{Identification of Micro-situations}

After formal introduction of the participants, facilitators, about the training course the first task was given to the participants to draw the maps of the selected districts in identifying four villages in a district on the basis of their micro- situations leading to irrigated and rainfed agriculture.

\section{Selection of village}

As a result of the orientation programme based on the distinct agro-ecological situations, presence of different agricultural enterprises, approach to the districts, security and other logistic criteria; two districts namely Balkh and Dawlat Abad were selected in Balkh province and Behsud and Rudat in Nangarhar province by the participants in the training programme. The local extension staff in each district was to carry out the PRA so as to identify important water and land resource problems that are confronting the different categories of farmers within the different micro-situations of each district, as well as to identify innovative farmers and other market opportunities that might be pursued in developing value-chains for potential high-value (HV) crop and livestock products.

The participants were randomly divided into two groups and were put to a task. At the completion of the task review, which was done by the facilitators in the general session and the concept of PRA was discussed with the live example of making the district map by the participants to confirm that "they know we do not know. The whole issue of participation and perception of the concerned persons regarding their life and condition is most important as it adds value to understanding and is important for sustainable development. The PRA training 
was started with twenty four participants and the training was based on experiential learning, in facilitation mode, through task cycle method. As a result, a task was given to the participants to select at least four villages in each identified district i.e. Balkh and Dawlat Abad in Balkh and Behsud and Rudat in Nangarhar; based on the major criteria of availability of irrigation water and also the other considerations in pursuing a farming systems approach, along with the security and logistic arrangements. The participants selected the villages in a district-wise group work, done in two groups on day one of this first exercise, and then they followed the method of mapping, discussion and finalization of their task results. During the discussion, based on the review of the groups work, the philosophy, rational, history and development of PRA were introduced by the facilitators. The participants identified the representative village as follows:

Table-1: Selection of districts and representative villages in Balkh Province

\begin{tabular}{|l|l|l|l|}
\hline Name of Districts & Name of Villages & $\begin{array}{l}\text { Major } \\
\text { Consideration }\end{array}$ & Location in the district \\
\hline Balkh & Hisarak & Irrigated & Northern part \\
\hline & Hiwad & Irrigated & Eastern part \\
\hline & Taraki & Less Water & Western part \\
\hline & Alkuchi & Less Water & Western part \\
\hline Dawlat Abad & Char Baghe Sayeddan & Irrigated & \\
\hline & Markez Wolus-Wali & Irrigated & Central part \\
\hline & Bagh Shor & Less Water & \\
\hline & Qarshigok & Less Water & \\
\hline
\end{tabular}

Table-2: Selection of districts and representative villages in Nangarhar Province

\begin{tabular}{|l|l|l|l|}
\hline Name of District & Name of Villages & $\begin{array}{l}\text { Major } \\
\text { Consideration }\end{array}$ & Location in the district \\
\hline Behsud & Naghlo & Irrigated & East \\
\hline & Khosh-gumbad & Irrigated & Central \\
\hline & Qala-e-janankhan & Irrigated & North \\
\hline Akhunzada & Irrigated & South \\
\hline & Baro & Rainfed & South west \\
\hline & Mazina & Rainfed & North \\
\hline & Hisarshahi & Rainfed & Central \\
\hline & Hisarak & Rainfed & Far north \\
\hline
\end{tabular}

\section{Participatory Rural Appraisal}

Participatory Rural Appraisal (PRA) was understood by the participants as a tool or methodology for understanding the perception, knowledge, skill, practice, and situation of the farmer and also to enhance their participation as input in the program planning process. The following section gives a brief account of the tools and techniques used to train the participants. The focus of the PRA training was on rational, philosophy, history and origin of PRA and trainees were informed that the three pillars of PRA were as follows:

\section{a. Behavior \& Attitude (B\&A)}


B\&A are to be observed and practiced at the personal level by the PRA team members, keeping in mind the following points: respecting people, learning from people, listening carefully, team work, etc.

\section{b. Methods/ Tools}

These skills have to be learned professionally and they develop over time with practice. This process covers mainly different tools and techniques of PRA, mainly designed to generate accurate information and to enhance people's participation.

\section{c. Sharing}

This element mainly covers the process part of conducting a PRA and is related to the sharing and analysis of information at different levels within the community, within the PRA team and with other PRA teams (in other districts and provinces) and participating institutions.

\section{PRA Teams}

A PRA sub-team consists of three persons were also identified by the district team itself for each village. It was decided to add 1-2 persons to each sub-team at the district level while the actual data collection work is being done.

\section{Finalization of Check list}

The requirement and need for information / data collection was initiated by the facilitators in light of district level SREP preparation specific to Afghanistan conditions. The check list was revised after getting the feed back of the Team members through a Group task specifically meant to identify the issues and enterprises relevant for Afghanistan.

\section{PRA Tools}

Details of the tools and techniques to which the participants were exposed to are given below:

\section{a. Semi-Structured Interview:}

PRA semi-structured interviews (SSI) are basically a skill rather than a tool. It can be used effectively alone or with other tools to get fuller meaning of the information collected in less time and with the full participation of the people. It is also used for Focused Group Discussion (FGD). Without following SSI, limited accurate information can be derived. By using SSI alone, especially when time is limited and task is high, much useful information can be derived. During the training, SSI was used effectively by the participants in generating information related to the check-list for preparation of SREP.

\section{b. Transect Map:}

The Trainees were informed about this unique PRA tool, i.e. transect. As a tool of PRA, it has a specific role in understanding the agricultural scenario of the village. This is the only tool in PRA that can give a full picture of the present agricultural status with precision. It provides a cross-sectional representation of the different farming situations, the enterprises/commodities and their comparison against the observed parameters. A transect is different than the resource map despite area of overlap. The resource map provides a birds- eye view of village with a focus on natural resources. It is generally done after a resource map and therefore, helps in triangulation. It is also helps in taking forward the process of problem identification, searching opportunities, solutions, options, indigenous technical knowledge (ITK) and success stories, etc 


\section{c. Maps}

Maps in PRA are different from other regular conventional maps in significant ways. It is made by the people on the ground with the local materials, not to the scale and fixed direction. It depicts what the local people believe to be relevant and important for them. Thus it reflects their perceptions of the social dimensions of their realities with the high degree of authenticity.

\section{i. Social Map:}

Social map is the most popular method in PRA. It seeks to explore the spatial dimension of people's realities. The focus here is on the depiction of habitation patterns and the nature of housing and social infrastructure like roads, school, drinking water, etc. Thus, the information related to understanding of the people, like the population data, education, occupation, number of workers engaged in agricultural / non-agricultural work, ethnic groups, and other information required in preparing the SREP that can be collected through social mapping. It is very strong tool of PRA and it is also useful in relation building with the local people.

\section{ii. Resource Map:}

Resource map is another popular PRA tool. The resource map focuses on the natural resources present within the areas controlled by the village or locality, especially land, soil, rivers, streams and other water bodies; hills, mountains, and forests, as well as other vegetation, etc. For agricultural purposes it may also depict the fields, types of commodities being produced or other enterprises located within the village. Thus, a resource map reflects how people view their own locality, based on their perception of their natural resources.

\section{d. Well-Being Ranking:}

Well-being ranking, also known as wealth ranking, is another PRA tool that is commonly used in ranking and grouping households on the basis of the detailed well-being criteria as perceived by the villagers themselves, rather than only on the basis of income and wealth. It is based on the perception of the people. It helps to understand the local people's conception of wealth, wellbeing and their views on socio-economic disparities between households. Well-being is culture specific and is difficult to measure. Well-being ranking, however, provides a unique method for exploring local people thinking on well-being. The concept of this particular tool of well-being ranking has been used to segregate the farming community to understand the types of holding and an assessment of total land they posses in the village.

\section{e. Trend Analysis:}

Trend analysis is a popular tool of PRA used to explore the time dimension of change in certain variables over span of time. It is thus people's account of the past and how things have changed and hence also provide a historical perspective. Trend analysis was exposed in the training programme to know the changes whether positive or negative with the reasons why, over the period of time, in relation to the area/number, total production and productivity of the major commodities within the major enterprise of the village.

\section{Issues/Problems Emerging out of PRA in selected Provinces/Districts}

The training on PRA tools and techniques, along with the discussion, and finalization of the check list for data collection through PRA by the different teams in selected villages was done at both Mazar-e-sharif and Jalalabad. After the successful completion of the training of Master Trainers, the mock PRA exercise the Team were sent to the villages selected for collecting information for a day, considering the time, cost and security constraints. The detailed analysis is yet to be done; however, the details of various issues identified by the PRA teams, and some 
success stories observed in the different villages/districts have been presented in the next chapter. The information has been presented for different provinces and for different micro-situations district-wise for arriving at the strategies to deal with these issues and the points of interventions that could be taken up.

Table-3: Issues / Problems Emerging out of PRA in selected Provinces/Districts

\begin{tabular}{|c|c|c|c|c|c|c|}
\hline \multirow{3}{*}{$\begin{array}{l}\text { Province } \rightarrow \\
\text { District } \rightarrow \\
\text { Micro Situation } \rightarrow \\
\end{array}$} & \multicolumn{4}{|c|}{ Balkh } & \multicolumn{2}{|c|}{ Nangarhar } \\
\hline & \multicolumn{2}{|c|}{ Balkh } & \multicolumn{2}{|c|}{ Daulatabad } & \multirow{2}{*}{\begin{tabular}{|l|} 
Behsud \\
Irrigated \\
\end{tabular}} & \multirow{2}{*}{$\begin{array}{l}\text { Rudat } \\
\text { Rainfed } \\
\end{array}$} \\
\hline & Irrigated & Rainfed & Irrigated & Rainfed & & \\
\hline \multicolumn{7}{|l|}{ Issues/Problems $\downarrow$} \\
\hline \multicolumn{7}{|l|}{ Natural Resources } \\
\hline \multicolumn{7}{|l|}{ Climate, Land and Soil } \\
\hline $\begin{array}{l}\text { Huge tracts of undulated } \\
\text { land }\end{array}$ & $\mathrm{Y}$ & $\mathrm{Y}$ & $\mathrm{Y}$ & $\mathrm{Y}$ & $\mathrm{N}$ & $\mathrm{Y}$ \\
\hline $\begin{array}{l}\text { Poor soil health due to } \\
\text { improper application of } \\
\text { organic matter }\end{array}$ & $\mathrm{Y}$ & $\mathrm{Y}$ & $\mathrm{Y}$ & $\mathrm{Y}$ & $\mathrm{Y}$ & $\mathrm{Y}$ \\
\hline $\begin{array}{l}\text { Unsustainable land use } \\
\text { practices involving } \\
\text { overgrazing, deforestation, } \\
\text { and cultivation of marginal } \\
\text { lands }\end{array}$ & $\mathrm{Y}$ & $\mathrm{Y}$ & $\mathrm{Y}$ & $\mathrm{Y}$ & $\mathrm{N}$ & $\mathrm{Y}$ \\
\hline $\begin{array}{l}\text { Variable climatic conditions } \\
\text { and low rainfall leading to } \\
\text { increased vulnerability to } \\
\text { drought }\end{array}$ & $\mathrm{Y}$ & $\mathrm{Y}$ & $\mathrm{Y}$ & $\mathrm{Y}$ & $\mathrm{Y}$ & $\mathrm{Y}$ \\
\hline $\begin{array}{l}\text { Cultivation of rangeland by } \\
\text { communities to mitigate the } \\
\text { effects of drought }\end{array}$ & $\mathrm{Y}$ & $\mathrm{Y}$ & $\mathrm{Y}$ & $\mathrm{Y}$ & $\mathrm{Y}$ & $\mathrm{Y}$ \\
\hline \multicolumn{7}{|l|}{ Water Resources } \\
\hline Severe water shortage & $\mathrm{N}$ & $\mathrm{Y}$ & $\mathrm{N}$ & $\mathrm{Y}$ & $\mathrm{N}$ & $\mathrm{Y}$ \\
\hline $\begin{array}{l}\text { Management of natural } \\
\text { water resources difficult due } \\
\text { to destruction of traditional } \\
\text { irrigation and water } \\
\text { harvesting infrastructure }\end{array}$ & $\mathrm{Y}$ & $\mathrm{Y}$ & $\mathrm{Y}$ & $\mathrm{Y}$ & $\mathrm{Y}$ & $\mathrm{Y}$ \\
\hline $\begin{array}{l}\text { Improper selection of crops } \\
\text { in water scarce areas putting } \\
\text { pressure on irrigation } \\
\text { sources }\end{array}$ & $\mathrm{Y}$ & $\mathrm{Y}$ & $\mathrm{Y}$ & $\mathrm{Y}$ & $\mathrm{Y}$ & $\mathrm{Y}$ \\
\hline $\begin{array}{l}\text { Lack of proper practices for } \\
\text { managing surface and } \\
\text { ground water resources }\end{array}$ & $\mathrm{Y}$ & $\mathrm{Y}$ & $\mathrm{Y}$ & $\mathrm{Y}$ & $\mathrm{Y}$ & $\mathrm{Y}$ \\
\hline $\begin{array}{l}\text { Poor management and } \\
\text { upkeep of state owned water } \\
\text { management schemes }\end{array}$ & $\mathrm{Y}$ & $\mathrm{Y}$ & $\mathrm{Y}$ & $\mathrm{Y}$ & $\mathrm{Y}$ & $\mathrm{Y}$ \\
\hline $\begin{array}{l}\text { Vegetation/ Forest cover/ } \\
\text { Range lands }\end{array}$ & & & & & & \\
\hline
\end{tabular}




\begin{tabular}{|c|c|c|c|c|c|c|}
\hline $\begin{array}{l}\text { Huge barren tracts leading to } \\
\text { desertification }\end{array}$ & $\mathrm{Y}$ & $\mathrm{Y}$ & $\mathrm{Y}$ & $\mathrm{Y}$ & $\mathrm{N}$ & $\mathrm{Y}$ \\
\hline $\begin{array}{l}\text { Illegal felling of forest trees } \\
\text { leading to fast removal of } \\
\text { vegetative cover from land }\end{array}$ & $\mathrm{Y}$ & $\mathrm{Y}$ & $\mathrm{Y}$ & $\mathrm{Y}$ & $\mathrm{Y}$ & $\mathrm{Y}$ \\
\hline $\begin{array}{l}\text { Poor vegetative cover } \\
\text { leading to reduced grazing } \\
\text { areas and soil erosion }\end{array}$ & $\mathrm{Y}$ & $\mathrm{Y}$ & $\mathrm{Y}$ & $\mathrm{Y}$ & $\mathrm{Y}$ & $\mathrm{Y}$ \\
\hline $\begin{array}{l}\text { Widespread degradation of } \\
\text { both forests and rangeland, } \\
\text { flooding, water scarcity due } \\
\text { to removal for vegetative } \\
\text { cover }\end{array}$ & $\mathrm{Y}$ & $\mathrm{Y}$ & $\mathrm{Y}$ & $\mathrm{Y}$ & $\mathrm{Y}$ & $\mathrm{Y}$ \\
\hline \multicolumn{7}{|l|}{$\begin{array}{l}\text { Agriculture production } \\
\text { systems }\end{array}$} \\
\hline \multicolumn{7}{|l|}{ Crop management } \\
\hline $\begin{array}{l}\text { Stagnant and low yield of } \\
\text { major cereal and other field } \\
\text { crops leading to low income } \\
\text { to the farm households }\end{array}$ & $\mathrm{Y}$ & $\mathrm{Y}$ & $\mathrm{Y}$ & $\mathrm{Y}$ & $\mathrm{Y}$ & $\mathrm{Y}$ \\
\hline $\begin{array}{l}\text { Non-availability of quality } \\
\text { seed material for wheat, } \\
\text { rice, maize, barley }\end{array}$ & $\mathrm{Y}$ & $\mathrm{Y}$ & $\mathrm{Y}$ & $\mathrm{Y}$ & $\mathrm{Y}$ & $\mathrm{Y}$ \\
\hline Low use of farm machinery & $\mathrm{Y}$ & $\mathrm{Y}$ & $\mathrm{Y}$ & $\mathrm{Y}$ & $\mathrm{Y}$ & $\mathrm{Y}$ \\
\hline $\begin{array}{l}\text { Standard package of } \\
\text { practices for different crops } \\
\text { not yet available }\end{array}$ & $\mathrm{Y}$ & $\mathrm{Y}$ & $\mathrm{Y}$ & $\mathrm{Y}$ & $\mathrm{Y}$ & $\mathrm{Y}$ \\
\hline $\begin{array}{l}\text { Huge gap in needs and } \\
\text { availability of Public } \\
\text { Extension functionaries at } \\
\text { district and village level to } \\
\text { handle the knowledge needs } \\
\text { of the farmers }\end{array}$ & $\mathrm{Y}$ & $\mathrm{Y}$ & $\mathrm{Y}$ & $\mathrm{Y}$ & $\mathrm{Y}$ & $\mathrm{Y}$ \\
\hline $\begin{array}{l}\text { Lack of mobility support to } \\
\text { extension staff leading to } \\
\text { their inability in moving to } \\
\text { the fields }\end{array}$ & $\mathrm{Y}$ & $\mathrm{Y}$ & $\mathrm{Y}$ & $\mathrm{Y}$ & $\mathrm{Y}$ & $\mathrm{Y}$ \\
\hline $\begin{array}{l}\text { Lack of awareness about the } \\
\text { Integrated Nutrient } \\
\text { Management (INM) and } \\
\text { Integrated Pest Management } \\
\text { (IPM) practices. }\end{array}$ & $\mathrm{Y}$ & $\mathrm{Y}$ & $\mathrm{Y}$ & $\mathrm{Y}$ & $\mathrm{Y}$ & $\bar{Y}$ \\
\hline $\begin{array}{l}\text { Non-adoption of soil test } \\
\text { based fertilizer application as } \\
\text { testing facilities do not exist } \\
\text { at district level }\end{array}$ & $\mathrm{Y}$ & $\mathrm{Y}$ & $\mathrm{Y}$ & $\mathrm{Y}$ & $\mathrm{Y}$ & $\mathrm{Y}$ \\
\hline $\begin{array}{l}\text { Non-availability of situation } \\
\text { specific varieties for field } \\
\text { crops }\end{array}$ & $\mathrm{Y}$ & $\mathrm{Y}$ & $\mathrm{Y}$ & $\mathrm{Y}$ & $\mathrm{Y}$ & $\bar{Y}$ \\
\hline Unorganized farmers & $\mathrm{Y}$ & $\mathrm{Y}$ & $\mathrm{Y}$ & $\mathrm{Y}$ & $\mathrm{Y}$ & $\mathrm{Y}$ \\
\hline
\end{tabular}




\begin{tabular}{|c|c|c|c|c|c|c|}
\hline $\begin{array}{l}\text { Tillage practices primitive } \\
\text { and causing loss of soil } \\
\text { physical properties }\end{array}$ & $\mathrm{Y}$ & $\mathrm{Y}$ & $\mathrm{Y}$ & $\mathrm{Y}$ & $\mathrm{Y}$ & $\mathrm{Y}$ \\
\hline $\begin{array}{l}\text { Fodder and forage crops not } \\
\text { given preference in crop } \\
\text { rotation leading to scarcity of } \\
\text { fodder }\end{array}$ & $\mathrm{Y}$ & $\mathrm{Y}$ & $\mathrm{Y}$ & $\mathrm{Y}$ & $\mathrm{Y}$ & $\bar{Y}$ \\
\hline $\begin{array}{l}\text { Lack of access to rural } \\
\text { finance }\end{array}$ & $\mathrm{Y}$ & $\mathrm{Y}$ & $\mathrm{Y}$ & $\mathrm{Y}$ & $\mathrm{Y}$ & $\mathrm{Y}$ \\
\hline $\begin{array}{l}\text { Lack of High value cash } \\
\text { crops in irrigated areas }\end{array}$ & $\mathrm{Y}$ & $\mathrm{Y}$ & $\mathrm{Y}$ & $\mathrm{Y}$ & $\mathrm{Y}$ & $\mathrm{Y}$ \\
\hline \multicolumn{7}{|l|}{ Water Management } \\
\hline $\begin{array}{l}\text { Lack of scientific on-farm } \\
\text { water management practices }\end{array}$ & $\mathrm{Y}$ & $\mathrm{Y}$ & $\mathrm{Y}$ & $\mathrm{Y}$ & $\mathrm{Y}$ & $\mathrm{Y}$ \\
\hline $\begin{array}{l}\text { Improper selection of crops } \\
\text { in areas with less water } \\
\text { availability }\end{array}$ & $\mathrm{Y}$ & $\mathrm{Y}$ & $\mathrm{Y}$ & $\mathrm{Y}$ & $\mathrm{Y}$ & $\mathrm{Y}$ \\
\hline $\begin{array}{l}\text { Predominantly Wheat-Rice } \\
\text { sequence followed, putting } \\
\text { pressure on irrigation } \\
\text { sources }\end{array}$ & $\mathrm{Y}$ & $\mathrm{Y}$ & $\mathrm{Y}$ & $\mathrm{Y}$ & $\mathrm{Y}$ & $\bar{Y}$ \\
\hline $\begin{array}{l}\text { Prolonged period of water } \\
\text { scarcity during growing } \\
\text { season affecting crop yields }\end{array}$ & $\mathrm{Y}$ & $\mathrm{Y}$ & $\mathrm{Y}$ & $\mathrm{Y}$ & $\mathrm{Y}$ & $\mathrm{Y}$ \\
\hline $\begin{array}{l}\text { Lack of suitable \& promising } \\
\text { crop varieties /cultivars for } \\
\text { rainfed conditions }\end{array}$ & $\mathrm{Y}$ & $\mathrm{Y}$ & $\mathrm{Y}$ & $\mathrm{Y}$ & $\mathrm{Y}$ & $\mathrm{Y}$ \\
\hline $\begin{array}{l}\text { Lack of proper package and } \\
\text { practices for crops in water } \\
\text { deficient areas }\end{array}$ & $\mathrm{Y}$ & $\mathrm{Y}$ & $\mathrm{Y}$ & $\mathrm{Y}$ & $\mathrm{Y}$ & $\mathrm{Y}$ \\
\hline $\begin{array}{l}\text { Mono cropping leading to } \\
\text { improper utilization of } \\
\text { natural resources }\end{array}$ & $\mathrm{N}$ & $\mathrm{Y}$ & $\mathrm{N}$ & $\mathrm{Y}$ & $\mathrm{N}$ & Y \\
\hline $\begin{array}{l}\text { Lack of scientifically } \\
\text { designed water harvesting } \\
\text { structures leading to wastage } \\
\text { of water }\end{array}$ & $\mathrm{Y}$ & $\mathrm{Y}$ & $\mathrm{Y}$ & $\mathrm{Y}$ & $\mathrm{Y}$ & $\mathrm{Y}$ \\
\hline Unorganized farmers & $\mathrm{Y}$ & $\mathrm{Y}$ & $\mathrm{Y}$ & $\mathrm{Y}$ & $\mathrm{Y}$ & $\mathrm{Y}$ \\
\hline $\begin{array}{l}\text { Horticulture Production } \\
\text { System }\end{array}$ & & & & & & \\
\hline
\end{tabular}




\begin{tabular}{|c|c|c|c|c|c|c|}
\hline $\begin{array}{l}\text { Under utilization of } \\
\text { horticulture based natural } \\
\text { resources }\end{array}$ & $\mathrm{Y}$ & $\mathrm{Y}$ & $\mathrm{Y}$ & $\mathrm{Y}$ & $\mathrm{Y}$ & $\mathrm{Y}$ \\
\hline $\begin{array}{l}\text { Poor maintenance and } \\
\text { upkeep of orchards }\end{array}$ & $\mathrm{Y}$ & $\mathrm{Y}$ & $\mathrm{Y}$ & $\mathrm{Y}$ & $\mathrm{Y}$ & $\mathrm{Y}$ \\
\hline $\begin{array}{l}\text { Very few new orchards } \\
\text { being planted in traditional } \\
\text { areas due to lack of water }\end{array}$ & $\mathrm{Y}$ & $\mathrm{Y}$ & $\mathrm{Y}$ & $\mathrm{Y}$ & $\mathrm{Y}$ & $\mathrm{Y}$ \\
\hline $\begin{array}{l}\text { Lack of good quality } \\
\text { saplings and quality seed } \\
\text { material for new plantations }\end{array}$ & $\mathrm{Y}$ & $\mathrm{Y}$ & $\mathrm{Y}$ & $\mathrm{Y}$ & $\mathrm{Y}$ & $\mathrm{Y}$ \\
\hline $\begin{array}{l}\text { Scientific fertigaton, training } \\
\text { and pruning not practiced in } \\
\text { orchards and plantations }\end{array}$ & $\mathrm{Y}$ & $\mathrm{Y}$ & $\mathrm{Y}$ & $\mathrm{Y}$ & $\mathrm{Y}$ & $\mathrm{Y}$ \\
\hline $\begin{array}{l}\text { Lack of Multi-purpose trees } \\
\text { for fodder and fuel. }\end{array}$ & $\mathrm{Y}$ & $\mathrm{Y}$ & $\mathrm{Y}$ & $\mathrm{Y}$ & $\mathrm{Y}$ & $\mathrm{Y}$ \\
\hline $\begin{array}{l}\text { Lack of training facilities for } \\
\text { nursery raising and plant } \\
\text { propagation }\end{array}$ & $\mathrm{Y}$ & $\mathrm{Y}$ & $\mathrm{Y}$ & $\mathrm{Y}$ & $\mathrm{Y}$ & $\mathrm{Y}$ \\
\hline $\begin{array}{l}\text { Knowledge and skill gap in } \\
\text { scientific production. }\end{array}$ & $\mathrm{Y}$ & $\mathrm{Y}$ & $\mathrm{Y}$ & $\mathrm{Y}$ & $Y$ & $\mathrm{Y}$ \\
\hline $\begin{array}{l}\text { Non-adoption of INM and } \\
\text { IPM practices. }\end{array}$ & $\mathrm{Y}$ & $\mathrm{Y}$ & $\mathrm{Y}$ & $\mathrm{Y}$ & $\mathrm{Y}$ & $\mathrm{Y}$ \\
\hline $\begin{array}{l}\text { Distress sale of fruits and } \\
\text { vegetables reducing } \\
\text { profitability }\end{array}$ & $\mathrm{Y}$ & $\mathrm{Y}$ & $\mathrm{Y}$ & $\mathrm{Y}$ & $\mathrm{Y}$ & $\mathrm{Y}$ \\
\hline Unorganized growers. & $\mathrm{YY}$ & $\mathrm{Y}$ & $\mathrm{Y}$ & $\mathrm{Y}$ & $\mathrm{Y}$ & $\bar{Y}$ \\
\hline $\begin{array}{l}\text { Lack of cooling and storage } \\
\text { facilities for fresh fruits and } \\
\text { vegetables. }\end{array}$ & $\mathrm{Y}$ & $\mathrm{Y}$ & $\mathrm{Y}$ & $\mathrm{Y}$ & $\mathrm{Y}$ & $\mathrm{Y}$ \\
\hline $\begin{array}{l}\text { Lack of post-harvest value } \\
\text { addition and handling } \\
\text { techniques }\end{array}$ & $\mathrm{Y}$ & $\mathrm{Y}$ & $\mathrm{Y}$ & $\mathrm{Y}$ & $\mathrm{Y}$ & $\mathrm{Y}$ \\
\hline $\begin{array}{l}\text { Reduced export earning } \\
\text { potential from Agro-forestry } \\
\text { and horticulture due to their } \\
\text { destruction }\end{array}$ & $\mathrm{Y}$ & $\mathrm{Y}$ & $\mathrm{Y}$ & $\mathrm{Y}$ & $\mathrm{Y}$ & $\mathrm{Y}$ \\
\hline \multicolumn{7}{|l|}{$\begin{array}{l}\text { Livestock Production } \\
\text { System }\end{array}$} \\
\hline $\begin{array}{l}\text { Lack of improved breeds of } \\
\text { sheep, goat and cattle }\end{array}$ & $\mathrm{Y}$ & $\mathrm{Y}$ & $\mathrm{Y}$ & $\mathrm{Y}$ & $\mathrm{Y}$ & $\mathrm{Y}$ \\
\hline $\begin{array}{l}\text { Lack of cross breeding and } \\
\text { AI programme }\end{array}$ & $\mathrm{Y}$ & $\mathrm{Y}$ & $\mathrm{Y}$ & $\mathrm{Y}$ & $\mathrm{Y}$ & $\mathrm{Y}$ \\
\hline $\begin{array}{l}\text { inadequate extension and } \\
\text { support services }\end{array}$ & $\mathrm{Y}$ & $\mathrm{Y}$ & $\mathrm{Y}$ & $\mathrm{Y}$ & $\mathrm{Y}$ & $\mathrm{Y}$ \\
\hline Poor health of livestock & Y & $\mathrm{Y}$ & $\mathrm{Y}$ & $\mathrm{Y}$ & $\mathrm{Y}$ & $\mathrm{Y}$ \\
\hline $\begin{array}{l}\text { Inadequate mobility and } \\
\text { supervision. }\end{array}$ & $\mathrm{Y}$ & $\mathrm{Y}$ & $\mathrm{Y}$ & $\mathrm{Y}$ & \begin{tabular}{|l} 
\\
\end{tabular} & $\mathrm{Y}$ \\
\hline $\begin{array}{l}\text { Inadequate livestock } \\
\text { assistants for door service. }\end{array}$ & Y & $\mathrm{Y}$ & $\mathrm{Y}$ & $\mathrm{Y}$ & $\mathrm{Y}$ & $\mathrm{Y}$ \\
\hline
\end{tabular}




\begin{tabular}{|c|c|c|c|c|c|c|}
\hline $\begin{array}{l}\text { Lack of proper health care to } \\
\text { animals/ birds }\end{array}$ & $\mathrm{Y}$ & $\mathrm{Y}$ & $\mathrm{Y}$ & $\mathrm{Y}$ & $\mathrm{Y}$ & $\mathrm{Y}$ \\
\hline $\begin{array}{l}\text { Severe shortage of green } \\
\text { fodder and poultry feed }\end{array}$ & $\mathrm{Y}$ & $\mathrm{Y}$ & $\mathrm{Y}$ & $\mathrm{Y}$ & $\mathrm{Y}$ & $\mathrm{Y}$ \\
\hline $\begin{array}{l}\text { Poor sanitation and housing } \\
\text { facilities for livestock and } \\
\text { birds }\end{array}$ & $\mathrm{Y}$ & $\mathrm{Y}$ & $\mathrm{Y}$ & $\mathrm{Y}$ & $\mathrm{Y}$ & $\mathrm{Y}$ \\
\hline $\begin{array}{l}\text { Unorganized marketing in } \\
\text { rural areas }\end{array}$ & $\mathrm{Y}$ & $\mathrm{Y}$ & $\mathrm{Y}$ & $\mathrm{Y}$ & $\mathrm{Y}$ & $\mathrm{Y}$ \\
\hline $\begin{array}{l}\text { Scientific knowledge and } \\
\text { skill gap among farmers }\end{array}$ & $\mathrm{Y}$ & $\mathrm{Y}$ & $\mathrm{Y}$ & $\mathrm{Y}$ & $\mathrm{Y}$ & $\mathrm{Y}$ \\
\hline $\begin{array}{l}\text { Limited financial back up } \\
\text { and insurance. }\end{array}$ & $\mathrm{Y}$ & $\mathrm{Y}$ & $\mathrm{Y}$ & $\mathrm{Y}$ & $\mathrm{Y}$ & $\mathrm{Y}$ \\
\hline $\begin{array}{l}\text { Unorganized market forcing } \\
\text { distress selling. }\end{array}$ & $\mathrm{Y}$ & $\mathrm{Y}$ & $\mathrm{Y}$ & $\mathrm{Y}$ & $\mathrm{Y}$ & $\mathrm{Y}$ \\
\hline \multicolumn{7}{|l|}{ Socio-economic Issues } \\
\hline $\begin{array}{l}\text { Fragmented and small land } \\
\text { holdings }\end{array}$ & $\mathrm{Y}$ & $\mathrm{Y}$ & $\mathrm{Y}$ & $\mathrm{Y}$ & $\mathrm{Y}$ & $\mathrm{Y}$ \\
\hline $\begin{array}{l}\text { Low involvement of women } \\
\text { in agriculture }\end{array}$ & $\mathrm{Y}$ & $\mathrm{Y}$ & $\mathrm{Y}$ & $\mathrm{Y}$ & $\mathrm{Y}$ & $\mathrm{Y}$ \\
\hline $\begin{array}{l}\text { Lack of access to credit, and } \\
\text { market, }\end{array}$ & $\mathrm{Y}$ & $\mathrm{Y}$ & $\mathrm{Y}$ & $\mathrm{Y}$ & $\mathrm{Y}$ & $\mathrm{Y}$ \\
\hline $\begin{array}{l}\text { Unorganized farming } \\
\text { community }\end{array}$ & $\mathrm{Y}$ & $\mathrm{Y}$ & $\mathrm{Y}$ & $\mathrm{Y}$ & $\mathrm{Y}$ & $\mathrm{Y}$ \\
\hline $\begin{array}{l}\text { Costly and spurious inputs } \\
\text { resulting in rise in cost of } \\
\text { production }\end{array}$ & $\mathrm{Y}$ & $\mathrm{Y}$ & $\mathrm{Y}$ & $\mathrm{Y}$ & $\mathrm{Y}$ & $\mathrm{Y}$ \\
\hline $\begin{array}{l}\text { Distress sale of produce due } \\
\text { to lack of money with the } \\
\text { farmers }\end{array}$ & $\mathrm{Y}$ & $\mathrm{Y}$ & $\mathrm{Y}$ & $\mathrm{Y}$ & $\mathrm{Y}$ & $\mathrm{Y}$ \\
\hline $\begin{array}{l}\text { Non-adoption of risk } \\
\text { minimizing and low cost } \\
\text { technologies. }\end{array}$ & $\mathrm{Y}$ & $\mathrm{Y}$ & $\mathrm{Y}$ & $\mathrm{Y}$ & $\mathrm{Y}$ & $\mathrm{Y}$ \\
\hline $\begin{array}{l}\text { Lack of post harvest, cold } \\
\text { storage, storage and } \\
\text { processing facilities in the } \\
\text { villages }\end{array}$ & $\mathrm{Y}$ & $\mathrm{Y}$ & $\mathrm{Y}$ & $\mathrm{Y}$ & $\mathrm{Y}$ & $\mathrm{Y}$ \\
\hline $\begin{array}{l}\text { Lack govt. supported } \\
\text { procurement and support } \\
\text { price leading to unstable } \\
\text { prices. }\end{array}$ & $\mathrm{Y}$ & $\mathrm{Y}$ & $\mathrm{Y}$ & $\mathrm{Y}$ & $\mathrm{Y}$ & $\mathrm{Y}$ \\
\hline $\begin{array}{l}\text { Limited knowledge about } \\
\text { governmental schemes. }\end{array}$ & $\mathrm{Y}$ & $\mathrm{Y}$ & $\mathrm{Y}$ & $\mathrm{Y}$ & $\mathrm{Y}$ & $\mathrm{Y}$ \\
\hline \multicolumn{7}{|l|}{ Institutional issues } \\
\hline $\begin{array}{l}\text { Lack of legal framework on } \\
\text { tenure, user rights, and } \\
\text { oversight responsibilities for } \\
\text { natural resources }\end{array}$ & $\mathrm{Y}$ & $\mathrm{Y}$ & $\mathrm{Y}$ & $\mathrm{Y}$ & $\mathrm{Y}$ & $\mathrm{Y}$ \\
\hline $\begin{array}{l}\text { Collapse of government } \\
\text { institutions, has led to the }\end{array}$ & $\mathrm{Y}$ & $\mathrm{Y}$ & $\mathrm{Y}$ & $\mathrm{Y}$ & $\mathrm{Y}$ & $\mathrm{Y}$ \\
\hline
\end{tabular}




\begin{tabular}{|c|c|c|c|c|c|c|}
\hline $\begin{array}{l}\text { control of natural resources } \\
\text { by local elites }\end{array}$ & & & & & & \\
\hline $\begin{array}{l}\text { Lack of suitable agency } \\
\text { having overall responsibility } \\
\text { for the protection of natural } \\
\text { resources }\end{array}$ & $\mathrm{Y}$ & $\mathrm{Y}$ & $\mathrm{Y}$ & $\mathrm{Y}$ & $\mathrm{Y}$ & $\mathrm{Y}$ \\
\hline $\begin{array}{l}\text { Lack of qualified manpower } \\
\text { for research and extension } \\
\text { work both at the national and } \\
\text { provincial level }\end{array}$ & $\mathrm{Y}$ & $\mathrm{Y}$ & $\mathrm{Y}$ & $\mathrm{Y}$ & $\mathrm{Y}$ & $\mathrm{Y}$ \\
\hline
\end{tabular}

\section{Critical issues their strategies and proposed intervention}

The issues/problems identified through the conducting of PRA in four selected districts of Balkh and Nangarhar provinces have been further analyzed, prioritized and identified as critical issues. The strategies and proposed interventions were summarized in this chapter and presented in Table-4.

Table-4: Critical issues their strategies and proposed intervention

\begin{tabular}{|c|c|c|c|}
\hline S.No & Critical Issues & Strategies & Proposed Interventions \\
\hline $\mathbf{A}$ & Natural Resources & & \\
\hline 1 & $\begin{array}{l}\text { Poor soil health due } \\
\text { to improper } \\
\text { application of } \\
\text { organic matter }\end{array}$ & $\begin{array}{l}\text { Capacity Building } \\
\text { and Training }\end{array}$ & $\begin{array}{l}\text { 1. Capacity building of the local communities and } \\
\text { farmers on Integrated Nutrient Management (INM). } \\
\text { 2. Development of leaflets, CDs, films and other material } \\
\text { in local language for distribution for popularizing the } \\
\text { new technology }\end{array}$ \\
\hline 2 & $\begin{array}{l}\text { Improper selection } \\
\text { of crops in water } \\
\text { scarce areas } \\
\text { putting pressure on } \\
\text { irrigation sources }\end{array}$ & $\begin{array}{l}\text { Training and } \\
\text { demonstration }\end{array}$ & $\begin{array}{l}\text { 1. Training and demonstration at the farmer's fields on } \\
\text { various rainfed crop and varieties. } \\
\text { 2. Development of leaflets, CDs, films and other material } \\
\text { in local language for distribution for popularizing the } \\
\text { new technology }\end{array}$ \\
\hline 3 & $\begin{array}{l}\text { Lack of proper } \\
\text { practices for } \\
\text { managing surface } \\
\text { and ground water } \\
\text { resources }\end{array}$ & $\begin{array}{l}\text { Exposure visits, } \\
\text { Training and } \\
\text { demonstration }\end{array}$ & $\begin{array}{l}\text { 1. Demonstration, training on methods for management } \\
\text { of surface and ground water. } \\
\text { 2. Exposure visits to successful sites where such methods } \\
\text { are being practiced. } \\
\text { 3. Development of leaflets, CDs, films and other material } \\
\text { in local language for distribution for popularizing the } \\
\text { new technology }\end{array}$ \\
\hline 4 & $\begin{array}{l}\text { Widespread } \\
\text { degradation of both } \\
\text { forests and } \\
\text { rangeland, } \\
\text { flooding, water } \\
\text { scarcity due to } \\
\text { removal for } \\
\text { vegetative cover }\end{array}$ & $\begin{array}{l}\text { Awareness and } \\
\text { capacity building of } \\
\text { the communities }\end{array}$ & $\begin{array}{l}\text { 1. Awareness programmes through participation of local } \\
\text { communities with the help of local NGOs. } \\
\text { 2. Exposure visit to sites where forest and rangeland } \\
\text { management practices under dry land conditions are } \\
\text { successfully demonstrated. } \\
\text { 3. Development of leaflets, CDs, films and other material } \\
\text { in local language for distribution for popularizing the } \\
\text { new technology }\end{array}$ \\
\hline B & Field Crops & Strategies & Proposed Interventions \\
\hline 1 & Stagnant and low & Diversification, & 1. Introduction of suitable high value crops like aromatic \\
\hline
\end{tabular}




\begin{tabular}{|c|c|c|c|}
\hline & $\begin{array}{l}\text { yield of major } \\
\text { cereal and other } \\
\text { field crops leading } \\
\text { to low income to } \\
\text { the farm } \\
\text { households }\end{array}$ & $\begin{array}{l}\text { value addition and } \\
\text { demonstration of } \\
\text { new technology }\end{array}$ & $\begin{array}{l}\text { and medicinal crops } \\
\text { 2. Market led value addition of the produce for } \\
\text { enhancing income of the farmer. } \\
\text { 3. Demonstration of new and improved technology for } \\
\text { filling the gap. } \\
\text { 4. Development of leaflets, CDs, films and other material } \\
\text { in local language for distribution for popularizing the } \\
\text { new technology/ intervention. } \\
\text { 5. Introduction of path breaking technologies like SRI } \\
\text { technology for rice cultivation and resource conservation } \\
\text { technologies like zero-tillage machines in rice wheat } \\
\text { cropping system. }\end{array}$ \\
\hline 2 & $\begin{array}{l}\text { Non-availability of } \\
\text { quality seed } \\
\text { material for wheat, } \\
\text { rice, maize, barley }\end{array}$ & $\begin{array}{l}\text { Mobilization, of } \\
\text { farmers for seed } \\
\text { production through } \\
\text { farmers } \\
\text { organization }\end{array}$ & $\begin{array}{l}\text { 1. Formation of farmer's interest groups (FIGs) on seed } \\
\text { production. } \\
\text { 2. Training, capacity building and demonstration of } \\
\text { suitable varieties. } \\
\text { 3. Exposure visits to successful sites where such farmer } \\
\text { groups are engaged in seed production. } \\
\text { 4. Handholding support to these groups for some time till } \\
\text { they are able to handle the affairs of their organization. } \\
\text { 5. Distribution of mini-kits of improved variety seeds } \\
\text { among farmer groups. } \\
\text { 6. Development of leaflets, CDs, films and other material } \\
\text { in local language for distribution for popularizing the } \\
\text { new technology }\end{array}$ \\
\hline 3 & $\begin{array}{l}\text { Low use of farm } \\
\text { machinery }\end{array}$ & $\begin{array}{l}\text { Awareness through } \\
\text { training, } \\
\text { demonstration }\end{array}$ & $\begin{array}{l}\text { 1. Demonstrations on zero tillage machines, for sowing } \\
\text { of wheat } \\
\text { 2. Some machines may be provided to FIGs willing to } \\
\text { use them on cost sharing basis. } \\
\text { 3. Development of leaflets, CDs, films and other material } \\
\text { in local language for distribution for popularizing the } \\
\text { new technology }\end{array}$ \\
\hline 4 & $\begin{array}{l}\text { Standard package } \\
\text { of practices for } \\
\text { different crops not } \\
\text { yet available }\end{array}$ & $\begin{array}{l}\text { On-farm research, } \\
\text { field trials and } \\
\text { validation }\end{array}$ & $\begin{array}{l}\text { 1. Research stations in both the provinces should take up } \\
\text { on-farm research on crops like wheat, rice, barley, maize, } \\
\text { oats, pulses, forage and oilseeds for developing situation } \\
\text { specific technology. } \\
\text { 2. Already available technological packages may be } \\
\text { validated under local conditions. } \\
\text { 3. Conduct technology validation trials on farmer's } \\
\text { fields, demonstration, and field days. } \\
\text { 4. Development and dissemination of standard package } \\
\& \text { practices for important crops through leaflets, CDs } \\
\text { and posters in Dari and Pashto for distribution among the } \\
\text { farmer groups. }\end{array}$ \\
\hline 5 & $\begin{array}{l}\text { Lack of mobility } \\
\text { support to } \\
\text { extension staff } \\
\text { leading to their } \\
\text { inability in moving } \\
\text { to the fields }\end{array}$ & $\begin{array}{l}\text { Providing support } \\
\text { to extension staff } \\
\text { for mobility in the } \\
\text { filed }\end{array}$ & $\begin{array}{l}\text { 1. Selected field extension functionaries in all the } \\
\text { districts, may be provided support in form of motor } \\
\text { cycles along with cost of fuel, to move into the field, for } \\
\text { conducting demonstrations, field days and other } \\
\text { extension activities. }\end{array}$ \\
\hline
\end{tabular}




\begin{tabular}{|c|c|c|c|}
\hline 6 & $\begin{array}{l}\text { Lack of awareness } \\
\text { about the Integrated } \\
\text { Nutrient } \\
\text { Management } \\
\text { (INM) and } \\
\text { Integrated Pest } \\
\text { Management (IPM) } \\
\text { practices. }\end{array}$ & $\begin{array}{l}\text { Training and } \\
\text { demonstration }\end{array}$ & $\begin{array}{l}\text { 1. Demonstration on farmers' fields to show effects of } \\
\text { INM\& IPM. } \\
\text { 2. Capacity building of farmers on INM and IPM } \\
\text { through some reputed institution. } \\
\text { 3. Providing IPM kit, and bio-pesticides on cost sharing } \\
\text { basis. } \\
\text { 4. Exposure visit to successful sites. } \\
\text { 5. Development of leaflets, CDs, films and other material } \\
\text { in local language for distribution for popularizing the } \\
\text { new technology }\end{array}$ \\
\hline 7 & $\begin{array}{l}\text { Non-adoption of } \\
\text { soil test based } \\
\text { fertilizer } \\
\text { application as } \\
\text { testing facilities do } \\
\text { not exist at district } \\
\text { level }\end{array}$ & $\begin{array}{l}\text { Training and } \\
\text { demonstration }\end{array}$ & $\begin{array}{l}\text { 1. Demonstration of INM in farmer's fields. } \\
\text { 2. Training of farmers and FIG members on use of low } \\
\text { cost Field Testing Kit. } \\
\text { 3. Providing low cost soil testing kits to the FIGs. } \\
\text { 4. Development of leaflets, CDs, films and other material } \\
\text { in local language for distribution for popularizing the } \\
\text { new technology }\end{array}$ \\
\hline 8 & $\begin{array}{l}\text { Non-availability of } \\
\text { situation specific } \\
\text { varieties for field } \\
\text { crops }\end{array}$ & $\begin{array}{l}\text { Adaptive research } \\
\text { on participatory } \\
\text { seed selection }\end{array}$ & $\begin{array}{l}\text { 1. On-farm participatory breeding trials. } \\
\text { 2. Testing of improved genotypes under different } \\
\text { situations. } \\
\text { 3. Making seeds available to the farmers/FIG under PPP. }\end{array}$ \\
\hline 9 & $\begin{array}{l}\text { Fodder and forage } \\
\text { crops not given } \\
\text { preference in crop } \\
\text { rotation leading to } \\
\text { scarcity of fodder }\end{array}$ & $\begin{array}{l}\text { Demonstration and } \\
\text { training on fodder } \\
\text { production }\end{array}$ & $\begin{array}{l}\text { 1. Demonstrations on forage crops under different micro- } \\
\text { situations. } \\
\text { 2. Introduction of new forage crops/varieties. } \\
\text { 3. Trainings on fodder management. } \\
\text { 4. Development of leaflets, CDs, films and other material } \\
\text { in local language for distribution for popularizing the } \\
\text { new technology }\end{array}$ \\
\hline 10 & $\begin{array}{l}\text { Lack of High value } \\
\text { cash crops in } \\
\text { irrigated areas }\end{array}$ & $\begin{array}{l}\text { Awareness, } \\
\text { Organizing HVC } \\
\text { growers, } \\
\text { Introduction of new } \\
\text { HV crops/ } \\
\text { varieties, } \\
\text { Demonstrations, } \\
\text { Training }\end{array}$ & $\begin{array}{l}\text { 1. Exposure visit for Farmers' and FIG leaders to areas } \\
\text { where HV crops are being grown/ cultivated. } \\
\text { 2. Introduction of new HV crops/ varieties based on } \\
\text { market demand. } \\
\text { 3. Testing the performance of these new HV crops/ } \\
\text { varieties under different micro-situations. } \\
\text { 4. Demonstrations to educate the farmers about new HV } \\
\text { crops/ Varieties. } \\
\text { 5. Providing market linkages to the Farmers' / FIG } \\
\text { growing these new crops. } \\
\text { 6. Development of leaflets, CDs, films and other material } \\
\text { in local language for distribution for popularizing the } \\
\text { new technology }\end{array}$ \\
\hline 11 & $\begin{array}{l}\text { Unorganized } \\
\text { farmers }\end{array}$ & $\begin{array}{l}\text { Awareness, } \\
\text { Exposure visits, } \\
\text { and Training }\end{array}$ & $\begin{array}{l}\text { 1. Success stories of successful groups to be shown to } \\
\text { willing farmers in form of films on their activities for } \\
\text { creating awareness. } \\
\text { 2. Formation of commodity based Farmer's Interest } \\
\text { Groups, with the help of local NGOs and other } \\
\text { community leaders. } \\
\text { 3. Exposure visits to successful areas/ enterprises where } \\
\text { group activities are running successfully. } \\
\text { 4. Training on group dynamics, record keeping and team }\end{array}$ \\
\hline
\end{tabular}




\begin{tabular}{|c|c|c|c|}
\hline & & & management, and marketing skills. \\
\hline $\mathbf{C}$ & $\begin{array}{l}\text { Water } \\
\text { management }\end{array}$ & Strategies & Proposed Interventions \\
\hline $\mathbf{1}$ & $\begin{array}{l}\text { Lack of scientific } \\
\text { on-farm water } \\
\text { management } \\
\text { practices }\end{array}$ & $\begin{array}{l}\text { Training, } \\
\text { Demonstration }\end{array}$ & $\begin{array}{l}\text { 1. Training the farmers on On-farm water management. } \\
\text { 2. Demonstration of improved water management } \\
\text { practices on farmer's field. } \\
\text { 3. Development of leaflets, CDs, films and other material } \\
\text { in local language for distribution for popularizing the } \\
\text { new technology }\end{array}$ \\
\hline 2 & $\begin{array}{l}\text { Lack of suitable \& } \\
\text { promising crop } \\
\text { varieties /cultivars } \\
\text { for rainfed } \\
\text { conditions }\end{array}$ & $\begin{array}{l}\text { Training, } \\
\text { Demonstration and } \\
\text { exposure visit }\end{array}$ & $\begin{array}{l}\text { 1. Trainings on water efficient crops/ varieties. } \\
\text { 2. Exposure visit to successful sites growing water } \\
\text { efficient crops. } \\
\text { 3. Demonstration of farmer's fields on suitable crops/ } \\
\text { varieties. } \\
\text { 4. Development of leaflets, CDs, films and other material } \\
\text { in local language for distribution for popularizing the } \\
\text { new technology }\end{array}$ \\
\hline 3 & $\begin{array}{l}\text { Lack of proper } \\
\text { package and } \\
\text { practices for crops } \\
\text { in water deficient } \\
\text { areas }\end{array}$ & Adaptive research & $\begin{array}{l}\text { 1. Adaptive research for developing package and } \\
\text { practices under rainfed conditions. } \\
\text { 2. Demonstration on the findings of adaptive research. } \\
\text { 3. Field days on research/ demonstration plots. } \\
\text { 4. Development of leaflets, CDs, films and other material } \\
\text { in local language for distribution for popularizing the } \\
\text { new technology. }\end{array}$ \\
\hline 4 & $\begin{array}{l}\text { Lack of } \\
\text { scientifically } \\
\text { designed water } \\
\text { harvesting } \\
\text { structures leading } \\
\text { to wastage of water }\end{array}$ & $\begin{array}{l}\text { Awareness, } \\
\text { Training, Exposure } \\
\text { visits, } \\
\text { Demonstration }\end{array}$ & $\begin{array}{l}\text { 1. Creating awareness about scientific water harvesting } \\
\text { structure through exposure visits to successful sites. } \\
\text { 2. Trainings on scientifically designed structures for } \\
\text { water harvesting. } \\
\text { 3. Demonstration on water-shed approach. }\end{array}$ \\
\hline 5 & $\begin{array}{l}\text { Unorganized } \\
\text { farmers }\end{array}$ & $\begin{array}{l}\text { Awareness, } \\
\text { Exposure visits, } \\
\text { and Training }\end{array}$ & $\begin{array}{l}\text { 1. Success stories of successful groups to be shown to } \\
\text { willing farmers in form of films on their activities for } \\
\text { creating awareness. } \\
\text { 2. Formation of Water User Association, with the help of } \\
\text { local NGOs and other community leaders for } \\
\text { Participatory Water management. } \\
\text { 3. Exposure visits to successful areas/ enterprises where } \\
\text { WUA activities are running successfully. } \\
\text { 4. Training on group dynamics, record keeping and team } \\
\text { management, and marketing skills. }\end{array}$ \\
\hline $\mathbf{D}$ & $\begin{array}{l}\text { Horticultural } \\
\text { Crops }\end{array}$ & Strategies & Proposed Interventions \\
\hline 1 & $\begin{array}{l}\text { Under exploitation } \\
\text { of horticulture } \\
\text { based natural } \\
\text { resources }\end{array}$ & $\begin{array}{l}\text { Diversification, and } \\
\text { intensification }\end{array}$ & $\begin{array}{l}\text { 1. Introduction of new } \mathrm{HV} \text { enterprises like beekeeping, } \\
\text { mushroom production, sericulture, medicinal and } \\
\text { aromatic plants, exotic vegetables in existing } \\
\text { horticultural production system . } \\
\text { 2. Training and demonstration on these new high value } \\
\text { crops. } \\
\text { 3. Exposure visits to areas where these enterprises are } \\
\text { being taken successfully. }\end{array}$ \\
\hline
\end{tabular}




\begin{tabular}{|c|c|c|c|}
\hline & & & $\begin{array}{l}\text { 4. Organizing farmers into commodity/ enterprise based } \\
\text { Farmer's Interest Groups, building their capacity and } \\
\text { providing market linkages. } \\
\text { 5. Development of leaflets, CDs, films and other material } \\
\text { in local language for distribution for popularizing the } \\
\text { new enterprises/ crops/ technologies. } \\
\text { 6. Collaboration of Sericulture department/institute of } \\
\text { Afghanistan with Indian Sericulture Institute in } \\
\text { Bangalore for capacity building and sharing of } \\
\text { experience. }\end{array}$ \\
\hline 2 & $\begin{array}{l}\text { Poor maintenance } \\
\text { and upkeep of } \\
\text { orchards }\end{array}$ & $\begin{array}{l}\text { Training and } \\
\text { Demonstration }\end{array}$ & $\begin{array}{l}\text { 1. Training of farmers/ FIGs on orchard management. } \\
\text { 2. Demonstration on farmer's field. } \\
\text { 3. Development of leaflets, CDs, films and other material } \\
\text { in local language for distribution for popularizing the } \\
\text { new technology }\end{array}$ \\
\hline 3 & $\begin{array}{l}\text { Very few new } \\
\text { orchards being } \\
\text { planted in } \\
\text { traditional areas } \\
\text { due to lack of water }\end{array}$ & $\begin{array}{l}\text { Training and } \\
\text { demonstration }\end{array}$ & $\begin{array}{l}\text { 1. Training the potential growers on micro-irrigation } \\
\text { techniques and its maintenance. } \\
\text { 2. Making saplings of fruits available to potential } \\
\text { growers for establishment of new orchards on cost } \\
\text { sharing. } \\
\text { 3. Demonstration on establishment of new orchard under } \\
\text { water scarce conditions on cost sharing basis. } \\
\text { 4. Making micro-irrigation kit available to new orchard } \\
\text { growers on cost sharing basis. } \\
\text { 5. Development of leaflets, CDs, films and other material } \\
\text { in local language for distribution for popularizing the } \\
\text { new micro-irrigation technology }\end{array}$ \\
\hline 4 & $\begin{array}{l}\text { Lack of good } \\
\text { quality saplings and } \\
\text { quality seed } \\
\text { material for new } \\
\text { plantations }\end{array}$ & $\begin{array}{l}\text { Training and } \\
\text { exposure visits }\end{array}$ & $\begin{array}{l}\text { 1. Training of farmer's/ farmer groups on plant } \\
\text { propagation techniques. } \\
\text { 2. Exposure visit to successful entrepreneur's orchard } \\
\text { doing similar work. } \\
\text { 3. Providing good quality mother plants to trained } \\
\text { farmers/ farmer groups for development of their own } \\
\text { nurseries. } \\
\text { 4. Hand holding support for some time, to new nurseries } \\
\text { for market linkages. } \\
\text { 5. Development of leaflets, CDs, films and other material } \\
\text { in local language for distribution for popularizing the } \\
\text { plant propagation and nursery raising. }\end{array}$ \\
\hline 5 & $\begin{array}{l}\text { Scientific } \\
\text { fertigaton, training } \\
\text { and pruning not } \\
\text { practiced in } \\
\text { orchards and } \\
\text { plantations }\end{array}$ & $\begin{array}{l}\text { Training and } \\
\text { exposure visits }\end{array}$ & $\begin{array}{l}\text { 1. Training the orchard growers on scientific } \\
\text { management of orchards. } \\
\text { 2. Exposure visits to scientifically managed orchards at } \\
\text { research stations/ Faculty of Agriculture. } \\
\text { 3. Development of leaflets, CDs, films and other material } \\
\text { in local language for distribution for popularizing the } \\
\text { new technology }\end{array}$ \\
\hline 6 & $\begin{array}{l}\text { Knowledge and } \\
\text { skill gap in } \\
\text { scientific } \\
\text { production. }\end{array}$ & Training & $\begin{array}{l}\text { 1. Trainings of farmers/ farmer groups on scientific } \\
\text { cultivation and skill improvement for growing fruit, } \\
\text { vegetable, and flowers. } \\
\text { 2. Development of leaflets, CDs, films and other material }\end{array}$ \\
\hline
\end{tabular}




\begin{tabular}{|c|c|c|c|}
\hline & & & $\begin{array}{l}\text { in local language for distribution for popularizing the } \\
\text { new cultivation technology for different fruit, vegetable } \\
\text { and fruit crops. }\end{array}$ \\
\hline 7 & $\begin{array}{l}\text { Non-adoption of } \\
\text { INM and IPM } \\
\text { practices. }\end{array}$ & $\begin{array}{l}\text { Training and } \\
\text { Demonstration }\end{array}$ & $\begin{array}{l}\text { 1. Training on INM and more specifically IPM in fruit } \\
\text { and vegetable crops. } \\
\text { 2. Demonstration on INM and IPM in fruit and vegetable } \\
\text { crops. } \\
\text { 3. Providing IPM kits and bio-pesticides to horticultural } \\
\text { farmers/ farmer's groups on cost sharing basis. } \\
\text { 4. Development of leaflets, CDs, films and other material } \\
\text { in local language for distribution for popularizing the } \\
\text { INM and IPM technology in horticultural crops. }\end{array}$ \\
\hline 8 & $\begin{array}{l}\text { Unorganized } \\
\text { growers }\end{array}$ & $\begin{array}{l}\text { Awareness, } \\
\text { Exposure visits, } \\
\text { and Training }\end{array}$ & $\begin{array}{l}\text { 1. Success stories of successful groups to be shown to } \\
\text { willing farmers in form of films on their activities for } \\
\text { creating awareness. } \\
\text { 2. Formation of commodity based Farmer's Interest } \\
\text { Groups, with the help of local NGOs and other } \\
\text { community leaders. } \\
\text { 3. Exposure visits to successful areas/ enterprises where } \\
\text { group activities are running successfully. } \\
\text { 4. Training on group dynamics, record keeping and team } \\
\text { management, and marketing skills. }\end{array}$ \\
\hline 9 & $\begin{array}{l}\text { Lack of post- } \\
\text { harvest value } \\
\text { addition and } \\
\text { handling } \\
\text { techniques }\end{array}$ & Training & $\begin{array}{l}\text { 1. Training of farmers and farm women on post harvest } \\
\text { management of fruit and vegetable crops. } \\
\text { 2. Training to farm women on flower cultivation, } \\
\text { harvesting, packaging and marketing. } \\
\text { 3. Training on grading, standardization, value addition, } \\
\text { packaging and marketing of fruit and vegetable crops. } \\
\text { 4. Development of leaflets, CDs, films and other material } \\
\text { in local language for distribution for popularizing the } \\
\text { post harvest management technology in horticultural } \\
\text { crops. }\end{array}$ \\
\hline $\mathbf{E}$ & $\begin{array}{l}\text { Livestock } \\
\text { Production }\end{array}$ & Strategies & Proposed Interventions \\
\hline 1 & $\begin{array}{l}\text { Lack of improved } \\
\text { breeds of sheep, } \\
\text { goat and cattle }\end{array}$ & $\begin{array}{l}\text { Awareness and } \\
\text { training }\end{array}$ & $\begin{array}{l}\text { 1. Training on importance of breed improvement. } \\
\text { 2. Exposure visit to animal farms rearing improved breed } \\
\text { of sheep goats and cattle. } \\
\text { 3. Organizing Cattle Fair and rewarding farmers rearing } \\
\text { improved breeds. } \\
\text { 4. Involving Para-vet services/ NGOs for creating } \\
\text { awareness about breed improvement. }\end{array}$ \\
\hline 2 & $\begin{array}{l}\text { Inadequate } \\
\text { extension and } \\
\text { support services for } \\
\text { livestock }\end{array}$ & Capacity building & $\begin{array}{l}\text { 1. Training unemployed youth in Para-vet services like } \\
\text { AI, animal health, nutrition, sanitation, and hygiene. } \\
\text { 2. Providing AI kits, relevant literature and other } \\
\text { equipment to the Para-vets on cost sharing basis. } \\
\text { 3. Development of leaflets, and other extension material } \\
\text { in local language for distribution through Para-vets on } \\
\text { AI, animal health, nutrition, sanitation, and hygiene. }\end{array}$ \\
\hline 3 & $\begin{array}{l}\text { Severe shortage of } \\
\text { green fodder and }\end{array}$ & $\begin{array}{l}\text { Training and } \\
\text { demonstration }\end{array}$ & $\begin{array}{l}\text { 1. Training the farmers on cultivation of fodder crops } \\
\text { and cattle/poultry feed preparation }\end{array}$ \\
\hline
\end{tabular}




\begin{tabular}{|c|c|c|c|}
\hline & poultry feed & & $\begin{array}{l}\text { 2. Demonstration on new fodder crops and improved } \\
\text { fodder varieties } \\
\text { 3. Training on range land management for green fodder } \\
\text { availability. } \\
\text { 4. Providing mini-kits of new fodder crops and improved } \\
\text { fodder varieties seeds to livestock owners and FIGs. } \\
\text { 5. Development of leaflets, and other extension material } \\
\text { in local language for distribution through Para-vets on } \\
\text { cultivation of green fodder and rangeland management. }\end{array}$ \\
\hline 4 & $\begin{array}{l}\text { Unorganized } \\
\text { marketing in rural } \\
\text { areas }\end{array}$ & $\begin{array}{l}\text { Capacity building } \\
\text { and group } \\
\text { formation }\end{array}$ & $\begin{array}{l}\text { 1. Success stories of successful farmers/ groups to be } \\
\text { shown to cattle/ herd owners in form of films on their } \\
\text { activities for creating awareness. } \\
\text { 2. Formation of FIGs on animal rearing and marketing, } \\
\text { with the help of local NGOs and other community } \\
\text { leaders. } \\
\text { 3. Exposure visits to successful areas/ enterprises where } \\
\text { group activities on marketing of milk, meat, hide and } \\
\text { other animal products are running successfully. } \\
\text { 4. Training on group dynamics, record keeping and team } \\
\text { management, and marketing skills. } \\
\text { 5. Hand holding support for market linkages with milk } \\
\text { processing industry, meat packaging industry, leather } \\
\text { industry and other such industries which use animal } \\
\text { products as a raw material. }\end{array}$ \\
\hline 5 & $\begin{array}{l}\text { Scientific } \\
\text { knowledge and } \\
\text { skill gap among } \\
\text { farmers }\end{array}$ & $\begin{array}{l}\text { Training and } \\
\text { demonstration }\end{array}$ & $\begin{array}{l}\text { 1. Training on scientific management of cattle and herd } \\
\text { to farmers and extension personnel. } \\
\text { 2. Development of leaflets, and other extension material } \\
\text { in local language for distribution through extension } \\
\text { functionaries and Para-vets on AI, animal health, } \\
\text { nutrition, sanitation, and hygiene. }\end{array}$ \\
\hline $\mathbf{F}$ & $\begin{array}{l}\text { Socio-economic } \\
\text { Issues }\end{array}$ & Strategies & Proposed Interventions \\
\hline 1 & $\begin{array}{l}\text { Lack of access to } \\
\text { credit, and market }\end{array}$ & Capacity building & $\begin{array}{l}\text { 1. Formation of commodity based Self Help Groups and } \\
\text { Farmer's Interest Groups, on thrift and savings with the } \\
\text { help of local NGOs and other community leaders. } \\
\text { 2. Training on group dynamics, record keeping and team } \\
\text { management, and marketing skills. } \\
\text { 3. Exposure visit to successful credit and thrift activities } \\
\text { at national/ international level for group leaders/ } \\
\text { extension functionaries. } \\
\text { 4. Capacity building of SHGs/ FIGs on market-led } \\
\text { production, developing market linkages, ITC enabled } \\
\text { marketing. } \\
\text { 5. Re-establishing the brand Made/ Produced in } \\
\text { Afghanistan particularly in areas like dry fruits, animal } \\
\text { products, cotton, wool, through professionally managed } \\
\text { Brand Building efforts. }\end{array}$ \\
\hline 2 & $\begin{array}{l}\text { Low involvement } \\
\text { of women in } \\
\text { agriculture }\end{array}$ & $\begin{array}{l}\text { Capacity building, } \\
\text { Training and } \\
\text { exposure }\end{array}$ & $\begin{array}{l}\text { 1. Organizing women in to groups for economic activity. } \\
\text { 2. Training women for value addition and post harvest } \\
\text { technology. }\end{array}$ \\
\hline
\end{tabular}




\begin{tabular}{|c|c|c|c|}
\hline & & & $\begin{array}{l}\text { 3. Exposure visit of women groups to successful areas } \\
\text { where such women groups are working }\end{array}$ \\
\hline 3 & $\begin{array}{l}\text { Lack of post } \\
\text { harvest, storage and } \\
\text { processing facilities } \\
\text { in the villages }\end{array}$ & $\begin{array}{l}\text { Training, capacity } \\
\text { building, exposure } \\
\text { visits and } \\
\text { demonstration }\end{array}$ & $\begin{array}{l}\text { 1. Trainings on Post harvest management, value addition, } \\
\text { storage, processing and packaging of local produce as } \\
\text { per market demand. } \\
\text { 2. Training on sustainable management of post harvest } \\
\text { facilities after hand holding is over. } \\
\text { 3. Dovetailing with other agencies which offer such } \\
\text { facilities to the farmers. } \\
\text { 4. Establishment of post harvest and storage facilities } \\
\text { like seed bank/ grain bank, in selected villages on pilot } \\
\text { basis to demonstrate their use and utility. } \\
\text { 5. Exposure visit to successful sites. }\end{array}$ \\
\hline 4 & $\begin{array}{l}\text { Limited knowledge } \\
\text { about governmental } \\
\text { and non- } \\
\text { governmental } \\
\text { schemes/ projects. }\end{array}$ & Awareness & $\begin{array}{l}\text { 1. Development and distribution of leaflets, and other } \\
\text { extension material in local language for distribution } \\
\text { through extension functionaries detailing the various } \\
\text { governmental/ non-governmental projects/ schemes, } \\
\text { their provisions, eligibility etc. for wider circulation. } \\
\text { 2. Starting of new programmes on radio and TV } \\
\text { providing information about various project/ schemes. } \\
\text { 3. Use of posters, bill boards, sign boards, news papers, } \\
\text { and other mass media to create awareness about projects/ } \\
\text { schemes and their provisions for farmers and farm } \\
\text { women. }\end{array}$ \\
\hline $\mathbf{G}$ & Institutional issues & Strategies & Proposed Interventions \\
\hline 1 & $\begin{array}{l}\text { Lack of qualified } \\
\text { manpower for } \\
\text { research and } \\
\text { extension work } \\
\text { both at the national } \\
\text { and provincial level }\end{array}$ & $\begin{array}{l}\text { Training and } \\
\text { capacity building }\end{array}$ & $\begin{array}{l}\text { 1. Establishment of high quality training/educational } \\
\text { facilities for research and extension functionaries } \\
\text { belonging to both public and private sectors, involved in } \\
\text { teaching, research and technology transfer for agriculture } \\
\text { and allied sectors. } \\
\text { 2. Provision for in-service issue based short term } \\
\text { trainings courses for research and extension workers. } \\
\text { 3. Providing adequate incentive for good extension } \\
\text { workers and those who are willing to upgrade their } \\
\text { knowledge and skills. } \\
\text { 4. Provision for up-gradation of formal educational } \\
\text { qualifications of the extension functionaries through state } \\
\text { support. } \\
\text { 5. Provision for Para-extension workers under PPP mode } \\
\text { for filling the gaps in manpower needs and availability. } \\
\text { 6. Providing mobility support and adequate financial } \\
\text { provisions for moving in the fields for extension work so } \\
\text { that can learn from the field. } \\
\text { 7. Providing adequate research facilities for addressing } \\
\text { issue related to crops/ enterprises under various micro } \\
\text { situations. } \\
\text { 8. Organization of interactive seminars and workshops } \\
\text { for sharing information among research and extension } \\
\text { workers from different provinces/ districts. } \\
\text { 9. Provision of visiting Faculty/ Researchers from other }\end{array}$ \\
\hline
\end{tabular}




\begin{tabular}{|l|l|l|}
\hline & & $\begin{array}{l}\text { countries with similar agro-climatic situation for building } \\
\text { the capacity of research and extension workers of the } \\
\text { country. }\end{array}$ \\
\hline
\end{tabular}

\section{Innovations and Success Stories}

Technological development and transfer through well organized agriculture research and extension organizations are key elements in increasing agricultural productivity and achieving national food security in most nations. In addition, if the current farming systems can be intensified and/or diversified, this technology transfer strategy can increase the incomes of small farm households; thereby, improving rural livelihoods. This approach is well suited in countries that have a well developed agricultural research and extension system. However, in Afghanistan, after two decades of conflict, the agricultural education, research and extension infrastructure is currently weak, so an alternative approach may be more appropriate in increasing farm income.

In most rural communities, there are innovative farmers who have the capacity and insight about how to utilize technical knowledge and market information in developing "innovative" production systems, including the diversification of their farming systems to increase farm income. It is important to recognize that these innovations may not be new in other countries or even in the same province, but they still may be real innovations in a particular community or district. In many cases, these potential innovations, if utilized by similar farm households operating under similar conditions, can be quickly up-scaled by using a farmer-to-farmer extension approach as has been successfully carried out in other countries, such as India. Following this extension strategy, it is possible to move more quickly in increasing farm incomes and improving rural livelihoods.

These "innovations" and success stories can be systematically investigated and documented by tracing the forward and backward linkages (i.e. market-to-farm and vice-versa) to determine the potential for these different high-value crops and/or products to be scaled-up in different communities or districts. Across most provinces and districts, there are many farmer-led innovations or success stories that could be implemented across many rural villages within Afghanistan. Many of these success stories are just waiting to be identified, documented and replicated; this is a primary purpose of conducting PRAs in each district and then in translating these findings into a strategic research and extension plan for each district. The purpose is clear; to first identify these success stories and then to determine whether these innovations can be replicated and scaled-up. As documented in the following success stories, some organizations, such as ICARDA, have begun promoting successful innovations on a small scale across different parts of Afghanistan. However, the goal should be to incorporate this strategy within the national agricultural extension system so that a much larger number of farm households can be reached in increasing farm income and improving rural livelihoods.

To accomplish this goal, it is essential that these success stories be documented through this participatory extension approach, so that the most promising innovations can be rapidly investigated and then scaled up to comparable farm households, who are operating under similar agronomic conditions. The following section outlines five such success stories, which illustrate how these types of innovations might be scaled-up within the target districts, provinces and/or across the country. In addition, from this first phase of PRA training, there is preliminary 
evidence that many more success stories are waiting to be identified and then scaled-up by implementing a strategic research and extension plan (SREP) for each district, which is the primary purpose of first conducing PRAs across all districts within Afghanistan.

\section{Success Story-1: Mint and Its Value Added Products: Novel Source of Income to Afghan Farmers $^{3}$}

Despite the best efforts and massive international aid, rural communities in Afghanistan are plagued with poverty. Some of the pre-requisites to create viable alternative livelihoods are introduction of easily adaptable alternative crops and income generating activities that could be managed using household labor with minimal requirements of specific machinery and special storage conditions. All efforts to provide alternative livelihoods are to be focused primarily on tapping the huge domestic market with enormous demand for basic to luxury goods. Further, it is not out of place to mention that lack of infra-structure, processing facilities, quality control, investment in industry and infrastructure, and unpredictable security situation, will continue to jeopardize the export possibilities in coming years.

ICARDA through establishment of small rural enterprises has transformed mint from a kitchen garden crop to commercial one; and has increased its income generating potential through simple value addition techniques coupled with increased market access and marketing skills of the rural families. Farmers' associations were organized and members were trained in growing mint using modern agronomical practices and in simple value addition techniques to enhance the marketability of mint and its products. Training and support was provided to attractively pack and market the dried-mint leaves; simple equipment were provided to the associations to manufacture 'Mint-Water' (distillate) as an effective remedy for common digestive ailments; and extract Mint-Oil as a by-product during the production of mint-distillate. It is important to mention that digestion related ailments and sufferings are very common in rural Afghanistan due to unavailability of safe drinking water, poor hygienic conditions, and absence of suitable health care facilities. Thus, local communities heavily depend on alternative therapies, offering an opportunity to introduce scientifically produced herbal remedies with the potential of generating a good income.

Hygienically produced and attractively packed mint-distillate is now available in the markets of four provinces, and Afghan Ministry of Health has approved its production and marketing. Currently, seven farmers' associations (including one exclusively of woman) established in Helmand, Kabul, Kunduz, and Nangarhar are involved in production and marketing of fresh and dried mint; mint-distillate and mint-oil.

Collectively, these associations have produced and sold more than 25,000 packets of dried mint; and 40,000 bottles of mint-distillate in Afghanistan, and have also tested marketing their products in Peshawar (Pakistan).

A comparison of income generated through fresh mint (without value addition) shows a $40 \%$ higher income over opium poppy cultivation; marketing of mint-distillate and dried mint fetches

\footnotetext{
${ }^{3}$ Source- J. Rizvi, M. Athar, K. Wadan, W. Rasuli, and A. R. Manan International Center for Agricultural Research in the Dry Areas, Afghanistan Program http://www.icarda.cgiar.org/APRP/APRP-AE/HMAP/abstract/rizviABS.htm
} 
a profit of 50-130 and $250 \%$, respectively. Newly introduced value addition techniques not only provide much needed off-farm income and employment opportunities while reducing human sufferings, these also contribute towards the Government of Afghanistan's over all strategy to reduce poppy cultivation.

\section{Success Story-2: Empowerment of farmers through Village-based Seed Enterprises in Nangarhar Province, Afghanistan ${ }^{4}$}

Under the Eastern Afghanistan Alternative Livelihoods Program (ALP-E), USAID has provided funding through Development Alternatives Inc to improve Afghan agriculture and increase the incomes of rural households. Work focuses on three components: adaptive research, technology transfer through demonstration, and village-based seed enterprises. Project implementation has begun, particularly on adaptive research and demonstrations since late 2005 in three target provinces of Kunar, Laghman and Nangarhar.

The seed component of the project aims at establishing 12 new village-based seed enterprises (VBSEs) in these provinces over the next two years. It will also support five existing VBSEs in Nangarhar, established under the USAID-funded RAMP project. The project has already established six new VBSEs in the three provinces, which have begun wheat seed multiplication. The VBSEs are responsible for seed production and marketing within and beyond their communities. At the end of the project each VBSE will produce and commercialize quality seed in a sustainable manner. ICARDA has established 17 Village-based Seed Enterprises (VBSEs) in three provinces in Eastern Afghanistan: Kunar, Laghman and Nangarhar through RAMP and ADP/E programs of USAID. Almost all VBSEs are engaged in seed production and marketing of wheat, rice and mung bean. In addition to providing equipment (tractors, seed cleaners) and inputs, ICARDA has trained VBSE members in production, processing and marketing seeds of staple crops like wheat, rice, mung bean and potato. During the 2006/07 season, the VBSEs produced over 900 tons of wheat seed and are multiplying seed of rice and mung bean.

The ALP organized the Jalalabad Ag-Fair 2007 on 4-5 September 2007. In 2008, the 17 VBSEs have collectively planted 669 ha and expected to produce about 2500 tonnes of wheat, rice, mung bean and potato seed for marketing. The Nangarhar Seed Company, an umbrella organization representing VBSEs in Nangarhar province, and established with ICARDA support, participated. It exhibited its high-quality seed and the seed cleaner and treater provided by ALP/ICARDA. The company's stall won a 'Special Prize for Innovation' at the Ag-Fair. ICARDA's work in organizing, supporting, and transforming VBSEs into sustainable enterprises has been acclaimed by visiting dignitaries. ICARDA also exhibited its achievements in adaptive research and technology transfer through demonstrations; and in a stall set up by ICARDAorganized Mint Producers Associations.

However, lack of centrally located proper storage facilities remained a major constraint for VBSEs. ICARDA negotiated with Afghanistan Small and Medium Enterprise Development to

\footnotetext{
${ }^{4}$ Source:

Javed Rizvi, ICARDA-Kabul, P.O. Box-1355, Kabul, Afghanistan, E-mail j.rizvi@ cgiar.org Khaled Wadan, ICARDA, Jalalabad, Nangarhar, Afghanistan; E-mail: k.wadan@cgiar.org
} 
provide support for constructing a seed storage facility. Behsood VBSE was the first beneficiary where the storage facility was constructed on land provided by one of its members. The model storage facility $(15 \mathrm{~m} \times 10 \mathrm{~m} \times 5 \mathrm{~m})$ at a cost of around $\$ 13,000$ has the capacity of more than 200 MT. The facility will help in maintaining seed quality and seed marketing. Each VBSE will require such facility for its promotion and seed marketing purposes. Farmers were very satisfied with the support provided by MAIL, ADP-E and ICARDA particularly in adaptive research, technology transfer and seed provisions through VBSEs and are committed to increase agricultural production and productivity in the face of global challenges in food security.

\section{Success Story-3: Afghan Farmers producing under contract - Farmer groups sign production contracts; the first of its kind in Afghanistan ${ }^{5}$}

Until recently, market risk was a ubiquitous characteristic of agricultural activities in Afghanistan. Most farmers would plant their crops hoping to find a market at harvest, which often resulted in substantial, loses due to spoilage and opportunistic practices of rural traders. On the other side of the chain, produce wholesalers were uncertain about the volumes and quality of products that would be available at harvest time, which prevented them from projecting sales.

USAID's Alternative Development Program for the Eastern Region (ADP/E) is introducing a series of innovations to increase the capacity of local farmers to produce more fruit and vegetables, improve quality and streamline market systems. However, these interventions needed to be complemented through the introduction market incentives and by reducing exposure to market risk. In June 2007 USAID's (ADP/E) initiated the facilitation of forward contracts between farmer groups and members of the Jalalabad Fruit and vegetable Wholesalers Association. The first auction for 110 MT of vegetables took place in February 2007, which increased to $364 \mathrm{MT}$ in the fall of the same year. In the spring of 2008 over 2,300 farmers will have sales contracts before sowing their fields as part of an initiative to link farmer groups with traders and animal feed companies; this initiative will result in sales of over $6,000 \mathrm{mt}$ valued at US\$1.2 million.

With USAID's assistance, participating farmers receive fair market prices for their harvest this year through the introduction of written sales contracts. In addition to the introduction of certainty in market operations, over 30,000 farmers have now access to quality inputs and technical assistance to increase productivity, improve product quality and market their produce more efficiently. USAID's ADP/E follows a Value Chain Approach, integrating men and women entrepreneurs from the Eastern region in the production and marketing of high-value crops and linking them to the local, regional and global value chains.

\section{Success Story-4: Innovation in Rice Cultivation- SRI Technology in Afghanistan ${ }^{6}$}

\footnotetext{
${ }^{5}$ Source- $w w w . d a i . c o m / p d f / A f g h a n \_F a r m e r s . p d f$

${ }^{6}$ http://ciifad.cornell.edu/SRI/afgPMISpres0907.pdf
} 
The system of rice intensification known as SRI - also as le Systéme de Riziculture Intensive in French and la Sistema Intensivo de Cultivo Arrocero* (SICA) in Spanish -- is a methodology for increasing the productivity of irrigated rice cultivation by changing the management of plants, soil, water and nutrients. SRI practices lead to healthier, more productive soil and plants by supporting greater root growth and by nurturing the abundance and diversity of soil organisms. The agro-ecological principles that contribute to SRI effectiveness have good scientific bases. SRI concepts and methods have been successfully adapted to upland unirrigated rice, and they are now being extrapolated to other crops like millet, wheat and sugar cane.

SRI does not require the purchase of new seeds or the use of new high-yielding varieties. Although the highest yields with SRI have been obtained from improved varieties, most traditional or local varieties of rice respond well to SRI practices and command a higher market price. And while chemical fertilizer and agrochemicals can be applied with SRI, their use is not required as organic materials (compost, manure or any decomposed vegetation) can give good or even better results at low cost. Farmers report that when SRI methods are used correctly, rice plants are better able to resist damage from pests and diseases, reducing or eliminating need for agrochemical protection.

Because plant populations are greatly reduced with SRI, seed costs are cut by $80-90 \%$, and because paddy fields are not kept continuously flooded, there are water savings of 25 to $50 \%$, a major benefit in many places. However, cessation of flooding means that increased weeding is required. If this is done with soil-aerating implements like a rotating hoe, this cost has a benefit of enhanced crop production.SRI does require skillful management of the factors of production and, at least initially, more labor, particularly for careful transplanting and for weeding. Since yield increases are usually 50 to $100 \%$, and possibly several times present levels, the returns to labor can be very great. The profitability of rice production can be greatly increased when yield goes up with a reduction in the costs of production. As farmers gain skill and confidence in SRI methods, their labor input in fact decreases, and over time SRI can even become labor saving compared with conventional rice-growing methods. SRI is a work in progress, with improvements continually being made, including better implements and techniques that further reduce labor requirements. Farmers are encouraged to make their own improvements in SRI methods and to share experience within the farming community. Yield is the most evident (and controversial) feature of SRI, but many other considerations are also driving its spread around the world. SRI can be made use of in Afghanistan as this country has great need for improving its food security without relying on external inputs

\section{SRI Introduced in Afghanistan}

The Aga Khan Foundation program operating in the north of the country first introduced SRI technology in Afghanistan in year 2007 in Baghlan and Takhar provinces. With support from the Aga Khan Foundation, SRI expert from India, P. Kishan Rao, trained farmers in Baghlan Province who have started demo-trials in three locations. Weeding emerged as the most significant difficulty; however, weed problems were handled by combining manual and mechanical weeding. Neighboring farmers who were skeptical about transplanting such tiny

http://ciifad.cornell.edu/SRI/listservs/sriupdate0308.html\#Afghanistan16 http://ciifad.cornell.edu/sri/countries/afghanistan/index.html 
seedlings are now impressed by plant growth. The number of tillers at 42 days after transplanting has reached 48 in some SRI plants. The plant growth achieved was impressive - as many as 120 tillers per plant at 96 days - but transplanting was done too late to capitalize upon the crops' potential given the short growing season there. AKF has organized visits and training for dozens of farmers involved in its programs and for others working with the German NGO, Agro-Action. SRI was introduced by the project in 2007 as part of its food security strategy with particular attention to efficient use and management of water by the farmers. While the initial efforts were not completely successful, one of the farmers got a yield of $490 \mathrm{~kg}$ from 500 sq.m. area $(9.8$ tons per hectare), which is considered a good achievement for a SRI beginner. A Cornell PhD student Mark Henning has also introduced SRI to an NGO, namely Joint Development Associates International, working around Mazar-e-Sharif in the north which is trying to up-scale it.

Success Story-5: Off-Season Mint production for greater profits.

Considering the prolonged winter season in Afghanistan, and also the scope for increasing the supply of fresh vegetable and mint during the seasons of scarcity, and to get better prices for their produce during off-season, local farmers with help from ICARDA, have started growing off-season vegetable in several provinces of Afghanistan including Nangarhar province.

Many farmers felt that they could not produce enough mint and vegetables to take advantage of the demand situation in the local as well as national market during winter season, although they could grow good quality vegetables round the year provided they had the appropriate technology like farmers in other countries. Most of the high value vegetables like mint, tomatoes, ridge guard, bitter guard, bottle guard, and snake guard can be produced in a plastic tunnel. Mint is a high value medicinal and aromatic plant, newly introduced by ICARDA, Afghanistan in Nangarhar province of Afghanistan. The success story of mint cultivation is being replicated also in other providences of Afghanistan by group approach and also its processing and marketing by the farmer association. It is interested to mention that in Kabuk an association of women started mint processing and its marketing. Mint is a crop cultivated during summer season. The growth and development of mint plant starts retarded and stunted during winter season. But at the same time the price of mint products goes up during winter season due to its market demand and supply phenomena. With the technical support of ICARDA, Afghanistan, Md. Ashaq, President of Mint Farmer -cum- Processor Association, Kale Bakhtan, Surkhod ,Nangarhar, Afghanistan experimented cultivation of mint during winter season under poly tunnel condition. Under 1000 $\mathrm{m} 2$ poly-tunnel area, he successfully cultivated mint and processed in his processing plant and earned more than 40,000 Afghani (\$800) in the winter season, when mint is usually not cultivated.. For his mint product he is getting an order not only from Afghanistan market but also from abroad specially Saudi and Middle East. The success story of mint cultivation under polytunnel during winter season is gaining a perfect case for replication and slowly more and more farmers are approaching ICARDA for help. Not only mint but the farmers are also replicating this experience for high value off- season vegetable cultivation in nearby area and fetching good income.

\section{Proposed Strategy for Up-Scaling the Innovations related to High Value Crops}

\section{Conducting a PRA to Assess Local Conditions and Potential Markets}

In order to identify what marketable crops might successfully be introduced into the study area, local conditions are assessed using various Participatory Rural Appraisal (PRA) techniques. However, most farmers are unaware of the commercial importance of these HV crops, making it 
necessary to conduct extension activities, such as exposure visits, to create farmer awareness about these potential economic opportunities. In addition, farmers are to be informed both about the need to conserve the biodiversity of these plants as well as the growing demand for these HV crop in national and international markets. In the process, farmers should be told about the economic importance of these crops as a viable alternative to the traditional food crops being produced in the district/ province. As a result of these extension activities, farmers will soon became receptive to the idea of cultivating these new high value crops.

After discussion among the research and extension workers who jointly carry out the PRA, it should be seen that there is an agreement on the HV crop to be introduced/ up-scaled becomes a part of their strategy. Also to be kept in mind is that even small and marginal farmers could successfully engage in cultivation of these crops. If a Strategic Plan for Research and Extension has been developed for the district, such crops should find a place in the diversification strategy and should be given priority within the Strategic Research and Extension Plan (SREP) for the district.

\section{Organizing Producers into Farmer Interest Groups and Farmer Associations}

Given the need to scale-up for the production of different high-value crops or products, the it is necessary to identify those specific crops that have a strong market demand and that can be profitably grown by small-scale farmers in the district with minimal risk, at the same time, Extension officers should start organizing the farmers into Farmers Interest Groups or FIGs. If adequate capacity to organize the farmers in to commodity based groups is not available with the Department, it is advisable to seek help from NGOs and other such organization which have some past experience in this area.

Organizing these groups is a challenge due to different social and economic issues, and it is difficult to bring all of these different social and economic groups together into one organization to carry out a common economic activity. Therefore, the strategy to be adopted should be to organize these FIGs around people from similar social and economic backgrounds, who share similar goals and objectives. A typical (village-level) FIG could have 15 to 20 farmers as members and, those village-level FIGs should share a common interest, such as the production and marketing of the specific high value crop. The village level FIGs may be federated at district level into a Farmers Association (FA) and these FAs, in turn, could eventually become federated at the provincial level into Farm Federations (FFs). The key in setting up these producer groups at the village, district and province level is to create the framework that could produce a substantial quantity of specific high value crops on a sustainable basis, thus making it economically viable for the buyer or the company to continuing sourcing the material from the same groups of farmers. In addition, a substantial farmer base that could be mobilized to produce specific HV crops to specification would be highly beneficial in negotiating future contracts and in securing good financial returns for its members. It should be understood that even small and marginal farmers could participate in cultivation of HV crops if they followed the group approach as this was necessary to create economies of scale in production and marketing operation, which as individual farmers it was difficult to achieve.

\section{Assessing the Market Demand for Specific High Value (HV) crops}


In order to successfully produce HV crops in the district, it is necessary to identify those crops where there was a stable and growing market for the product. The identification of potential markets proved to be a difficult task, since most pharmaceutical companies engage in an inefficient, secretive and somewhat opportunistic process of sourcing medicinal plants. As a result, the trade in MAPs has been largely unregulated and carried out through a plethora of small-scale traders. To find genuine buyers and to determine the demand for these crops, several public agencies working in this field were contacted. In addition, the Internet was used to identify companies who are manufacturing traditional drugs. However, the initial interaction with most buyers did not prove to be encouraging, since most merchants were not interested in entering into a long-term contract, and the amount of raw materials needed depended on market demand for their products. Next, a more systematic and intensive effort should be undertaken by the extension officers to investigate the market demand for specific HV crops. Securing a credible market is essential to the success of this activity. Once the buyers/companies are shortlisted in efforts should be made to develop a partnership between the growers and the company so that successful supply chains can be established with each firm.

\section{Training FIG members to Produce and Handle HVCs}

The FIGs should be trained to produce and handle these different HVCs efficiently and the training these interested members from the FIGs has to be carried out by a team of experts from that field they may include: teachers and scientists from Faculties of Agriculture and research institutions; some NGO which has the requisite expertise and if need be the experts may be brought from neighboring country where such HVCs are being grown. The local Research Station should be the other key organization in this process, since they would be required to carry out field research on the production technologies that appeared most suitable for the district and validate it under the local conditions. The field where these adaptive trials are being carried out, and could become a key demonstration and training site; for future groups of farmers who wish to under production of these HVCs. Technical publications are to be prepared in the local language that explains cultivation practices so that these extension materials can enhance farmer's learning. Care should be taken to explain the economics of producing and marketing HVCs. The selection of trainees is to be done in consultation with the Head man of the village, local NGOs and progressive farmers of the area. To augment capacity building among each FIG, efforts should be made to select farmers who were more responsive to adopting new cultivation techniques. These selected farmers can then act as resource persons within each FIG to provide technical support to the other members.

Initially, the inputs such as seeds, fertilizers, organic manures and plant protection measures should be provided by the Extension Department on a cost sharing basis, later they can procure them from the open market themselves.

\section{Monitoring the Production and Post-Harvest Handling of HVC}

The production of the HV crops has to be carefully monitored by both Extension and Research officials to ensure that they were producing as per the requirements of the buyers/ company. If possible the visits by the representatives from the purchasing company may also be organized periodically to ensure that proper package of practices were being followed by the participating FIGs. After harvest, the HV crop should be handled as per the buyer's specifications and needs. Quality tests if needed will then be performed on the samples taken from each lot. The representatives from Extension and Research should be present at each stage of this process to 
ensure that the terms of the contract were carefully adhered to by the FIGs and the buyer/ company.

\section{References}

Singh, J.P., Swanson, B.E. \& Singh, K.M. 2006. Developing a decentralized, market-driven extension system in India: The ATMA model. In A.W. van den Ban and R.K. Samanta, eds. Changing roles of agricultural extension in Asian nations, pp. 203-223. Delhi, B.R. Publishing.

Singh, J.P., Swanson, B.E and Singh K.M.2005. Developing a Decentralized, Market-Driven Extension System in India: The ATMA Model. Good Practice Paper prepared for the World Bank, Washington DC.

Singh, K.M. 2004. Successful cultivation and processing of aromatic plants. In Setting paradigms: an anthology of success stories. Innovations in Technology Dissemination (ITD) Component of the National Agricultural Technology Project (NATP).

Singh, K.M. 2006. Impact of ATMA Model in Agricultural Extension System in Bihar- A Case Study of Pilot Project Districts, World Bank, India Office, New Delhi. P.78.

Singh, K.M. and Jha, A. K., 2012. Innovative Approaches in Technology Dissemination: Experiences of ATMA Model in Bihar. http://dx.doi.org/10.2139/ssrn.2168646

Singh, K.M., Swanson, B.E., Jha, A. K. and Meena, M. S., 2012. Extension Reforms and Innovations in Technology Dissemination - The ATMA Model in India.http://dx.doi.org/10.2139/ssrn.2168642

Singh, K.M., Swanson, B.E. \& Singh, J.P. 2005. Development of supply chains for medicinal plants: a case study involving the production of vinca rosa by small farmers in the Patna District of Bihar India. Paper presented at the Post-IAMA Workshop on Building New Partnerships in the Global Food Chain, June 2005, Chicago, IL.

Swanson, Burton E. 2008. Redefining Agricultural Extension's Role in Achieving Sustainable Rural Development. International Journal of Extension Education, Vol.4.September, 2008. pp-112.

Swanson, Burton E. 2008. Global Review of Good Agricultural Extension and Advisory Service Practices. Rsearch and Extension Division, Natural Resources Management and Environment Department and Policy Assistance and Resources Mobilization Division, Technical Cooperation Department. Food and Agriculture Organization of the United Nations. http://www.fao.org/nr/ext/ext_en.htm 
Swanson, Burton E., Singh, Krishna M. and Reddy, M. N., 2008. A Decentralized, Participatory, Market-Driven Extension System: The ATMA Model in

India.http://dx.doi.org/10.2139/ssrn.2168648 